\title{
HASTINGSITIC HORNBLENDES FROM THE AKAGANE DISTRICT, KITAKAMI MOUNTAINS, JAPAN
}

\author{
Satoshi Kanisawa
}

Department of Earth Science, College of Arts \& Sciences, Tohoku University, Sendai.

\begin{abstract}
In the Akagane district, Iwate Prefecture, bluish green hornblendes are frequently observed in the silicified parts of thermally metamorphosed dacitic tuff, forming small veins and clots. Three hornblendes separated from the TA-7 drill cores in the district were chemically analysed. They belong to ferrohastingsite, rich in $\mathrm{Fe}^{+2}$ and $\mathrm{Fe}^{+\mathrm{a}}$, with $\mathrm{mg}=0.10$ -0.30 .
\end{abstract}

\section{INTRODUGTION}

Although hastingsitic hornblendes are frequently found in alkaline to subalkaline igneous rocks, their occurrences are rather uncommon in the skarn zones or contact aureoles around the igneous rocks in Japan. They have been reported only from the contact aureoles of the Tabashine granodiorite mass, Iwate Prefecture (Watanabe \& Yagi, 1953), from the Obira Mine, Oita Prefecture (Miyahisa \& Matsumoto, 1959, Matsumoto \& Miyahisa, 1960), Kimbu Mine, Nagano Prefecture (Matsumoto, 1968), and Moji Mine, Fukuoka Prefecture (Matsumoto, 1969).

Hastingsitic hornblendes described in this paper were found as small veins or clots in the thermally metamorphosed dacitic tuff from the TA-7 drill core situated about $600 \mathrm{~m}$ away from the contact of the Hitokabe granodiorite.

The author wishes to thank Professor $\mathrm{K}$. Yagi for critical reading of the manuscript and valuable advices. $\mathrm{He}$ is also grateful to the staff of the Metallic Mineral Exploration Agency of Japan, who gave him opportunities to examine the drill cores.

\section{OCCURRENGES OF HASTINGSITIG HOR- NBLENDES}

The Akagane district is well-known for the development of many contact deposits of copper and iron, and detailed geological surveys have been carried out (Watanabe \& Ko, 1942, Aizawa, 1966, Nambu et al., 1970). The country rocks of the district is composed of andesitic to dacitic lavas and their tuffs of the Yonesato Formation, and of limestone and slate of the Shiba Formation, both of which belong to the Carboniferous. The Hitokabe granodiorite and other small stocks of diorite, gabbro, quartz porphyry and granite porphyry intruded into the Carboniferous formations.

Bluish green to greenish blue coloured hastingsitic hornblendes are widely distributed in the TA-7 drill cores which are situated to the west of the Sakae deposit, Akagane Mine, about $600 \mathrm{~m}$ away from the contact of the Hitokabe granodiorite (Fig. 1). Columnar section of the TA-7 drill core is shown in Fig. 2. The dacitic tuff and slate belonging to the Yonesato

(Manuscript received, May 28, 1974) 

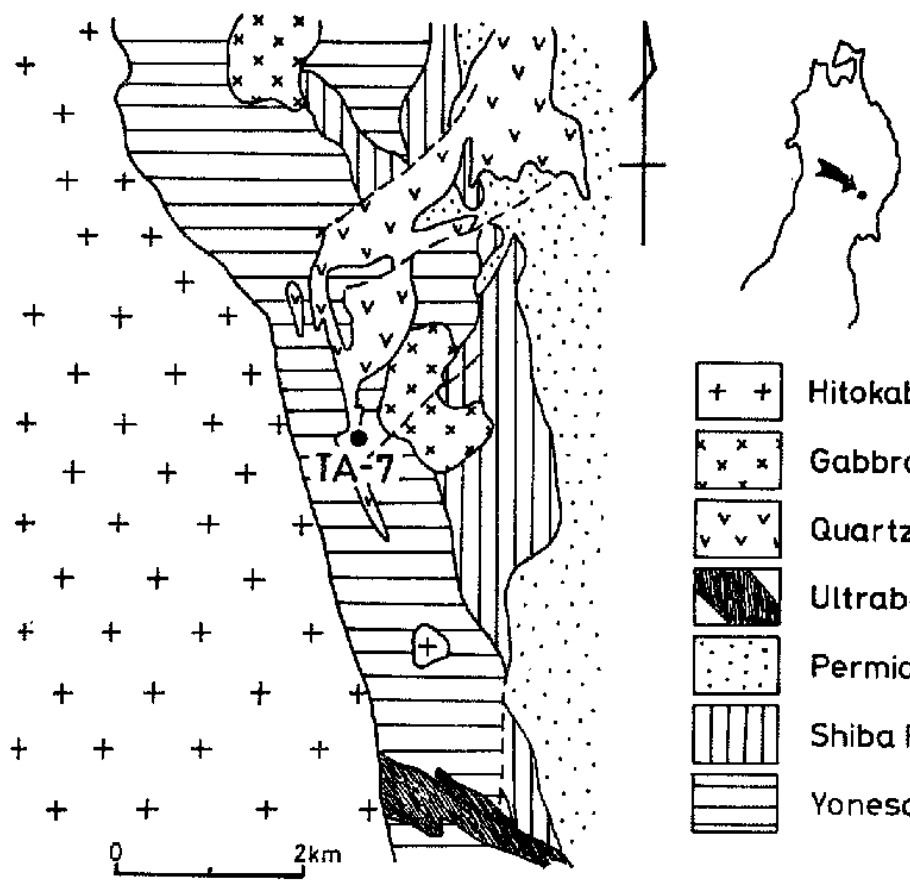

++ Hitokabe granodiorite

x Gabbro

$v^{2}$ Quartz porphyry,granite porphyry

Nithin Ultrabasic rocks

$\because \vdots:$ Permian Formations

Fig. 1. Simplified geological map of the Akagane district and the location of TA-7 drill hole.

Formation, and diorite-gabbro and quartz porphyry which intruded into them are observed in this column. All the rocks of the drill core suffered thermal metamorphism belonging to amphibolite facies and partly skarnization by the Hitokabe' granodiorite.

Hastingsitic hormblendes are frequently concentrated in the silicified parts of dacitic tuff and sometimes andesitic tuff, forming small veins or heterogeneous clot, dark green to black in colour. Hastingsitic homblendes are associated with large amount of quartz, subordinate amount of plagioclase, epidote, and sphene, and occasionally clinopyroxene, allanite, axinite, pyrrhotite, pyrite, tourmaline and calcite. They are hypidiomorphic granular and bluish green to greenish blue in $Z$-axial colour. Twinning on (100) is extremely rare. Their optical properties are listed in Table 1.

\section{ChemistRy OF hASTINGSITIC HORN- BLENDES}

Three hastingsitic hornblendes separated from the TA-7 drill cores at the depth of $219.7 \mathrm{~m}, 331.2 \mathrm{~m}$ and $433.8 \mathrm{~m}$, respective$1 y$, were chemically analysed with the results shown in Table 2 . It is clear that all hornblendes are very rich in $\mathrm{Fe}^{+2}$ and $\mathrm{Fe}^{+3}$, and fairly rich in $\mathrm{K}_{2} \mathrm{O}$ as compared with $\mathrm{Na}_{2} \mathrm{O}$, with $\mathrm{Ca}+\mathrm{Na}+\mathrm{K}>2.5$. Their $\mathrm{FeO} /$ $\mathrm{MgO}$ ratio exceeds 2.5 and Niggli's $\mathrm{mg}=$ $0.10-0.30$. Therefore, these hornblendes are called ferrohastingsite by Billings' (1928) classification, though their $\mathrm{Si}$ content is slightly high. According to Leake's classification (1968), Nos. 1 and 2 hornblendes belong to ferro-edenitic hornblende and No. 3 hormblende to magnesio-hastingsitic hornblende, because they are comparatively rich in $\mathrm{Si}(6.39-6.64) . \quad \mathrm{Fe}^{+3} \rightleftarrows \mathrm{Al}^{\mathrm{vI}}+\mathrm{Ti}$ substitu- 
Hastingsitic homblendes from the Akagane district, Kitakami mountains, Japan

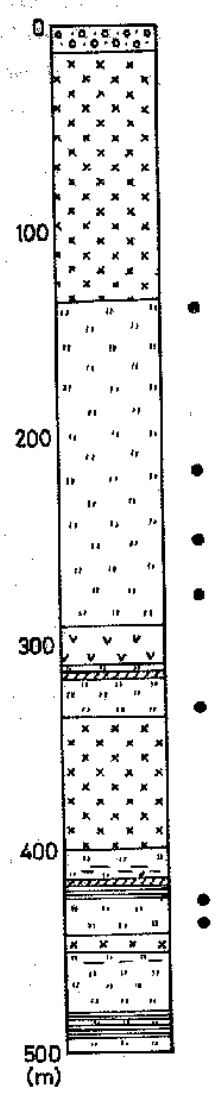

Fig. 2. Columnar section of the TA-7 drill hole.

Table 1. Optical properties and associated minerals of analysed hastingsitic hornblendes from the TA-7 drill cores

\begin{tabular}{|c|c|c|c|c|}
\hline $\begin{array}{c}\text { No. } \\
\text { Oeptrinfal }\end{array}$ & & $\begin{array}{c}1 \\
219.7 \\
\end{array}$ & $\begin{array}{c}2 \\
337.2\end{array}$ & $\begin{array}{c}3 \\
433,8\end{array}$ \\
\hline Pledechro1sm & $\begin{array}{l}x \\
y \\
z\end{array}$ & $\begin{array}{c}\text { greenish yellow } \\
\text { deep green } \\
\text { deep gremish blue }\end{array}$ & $\begin{array}{l}\text { yellaw } \\
\text { deep green } \\
\text { greenish blue }\end{array}$ & $\begin{array}{c}\text { pä le yel low } \\
\text { green } \\
\text { bluish green }\end{array}$ \\
\hline $\begin{array}{l}\text { Refractive } \\
\text { indices }\end{array}$ & & $\begin{array}{l}1.701 \\
1.722 \\
\end{array}$ & $\begin{array}{l}1.698 \\
1.713 \\
\end{array}$ & $\begin{array}{l}1.674 \\
1.700 \\
\end{array}$ \\
\hline $2 v_{x}$ & & $11^{\circ}$ & $6.5^{\circ}$ & $35^{\circ}-51^{\circ}$ \\
\hline$c \wedge z$ & & $11^{\circ}$ & n.d. & $20^{\circ}$ \\
\hline $\begin{array}{l}\text { Associated } \\
\text { minerais }\end{array}$ & & $\begin{array}{l}\text { quartz } \\
\text { plagioclase } \\
\text { clinoptyroxene } \\
\text { epidote } \\
\text { axinite } \\
\text { tourmaline } \\
\text { sphene } \\
\text { pyrrhot1te } \\
\text { pyrite } \\
\text { thalcopyrite } \\
\text { magnett te }\end{array}$ & $\begin{array}{l}\text { quiartz } \\
\text { plagioclase } \\
\text { epidote } \\
\text { allanita } \\
\text { leucoxene }\end{array}$ & $\begin{array}{l}\text { quartz } \\
\text { Dlagiociase } \\
\text { clinopyroxene } \\
\text { epionte } \\
\text { calcite } \\
\text { sphere } \\
\text { tourmaline }\end{array}$ \\
\hline
\end{tabular}

Table 2. Chemical analyses of hastingsitic hornblendes from the TA-7 drill cores, Iwate Prefecture

\begin{tabular}{lrrr}
\hline & \multicolumn{1}{c}{1} & \multicolumn{1}{c}{2} & \multicolumn{1}{c}{3} \\
\cline { 2 - 4 } $\mathrm{SiO}_{2}$ & 42.27 & 41.51 & 41.24 \\
$\mathrm{TiO}_{2}$ & 0.44 & 0.55 & 0.68 \\
$\mathrm{Al}_{2} \mathrm{O}_{3}$ & 9.53 & 10.78 & 11.29 \\
$\mathrm{Fe}_{2} \mathrm{O}_{3}$ & 8.20 & 7.61 & 5.47 \\
$\mathrm{FeO}^{2}$ & 21.22 & 21.02 & 18.64 \\
$\mathrm{MnO}$ & 0.59 & 0.30 & 0.30 \\
$\mathrm{MgO}$ & 1.95 & 2.23 & 5.65 \\
$\mathrm{CaO}$ & 10.55 & 10.58 & 11.85 \\
$\mathrm{Na}_{2}{ }^{0}$ & 1.47 & 1.58 & 1.18 \\
$\mathrm{~K}_{2} \mathrm{O}$ & 1.42 & 1.49 & 1.42 \\
$\mathrm{H}_{2}{ }^{0+}$ & 2.02 & 1.85 & 1.92 \\
$\mathrm{H}_{2} \mathrm{O}$ & 0.11 & 0.05 & 0.00 \\
$\mathrm{Tota}^{\mathrm{O}}$ & 99.77 & 99.55 & 99.64 \\
\hline
\end{tabular}

Numbers of ions on the basis of $24(0,0 \mathrm{H})$

\begin{tabular}{cccc}
$\mathrm{Si}$ & 6.643 & 6.531 & 6.386 \\
$\mathrm{AT}^{\mathrm{IV}}$ & 1.357 & 1.469 & 1.614 \\
$\mathrm{~A}^{\mathrm{VI}}$ & 0.404 & 0.527 & 0.443 \\
$\mathrm{Ti}^{\mathrm{i}}$ & 0.052 & 0.065 & 0.079 \\
$\mathrm{Fe}^{+3}$ & 0.967 & 0.899 & 0.636 \\
$\mathrm{Fe}^{+2}$ & 2.779 & 2.756 & 2.405 \\
$\mathrm{Mn}$ & 0.078 & 0.040 & 0.039 \\
$\mathrm{Mg}$ & 0.460 & 0.527 & 1.313 \\
$\mathrm{Ca}$ & 1.776 & 1.783 & 1.966 \\
$\mathrm{Na}$ & 0.447 & 0.481 & 0.353 \\
$\mathrm{~K}$ & 0.285 & 0.300 & 0.281 \\
$\mathrm{OH}$ & 2.116 & 1.947 & 1.983 \\
$Z$ & 8.000 & 8.000 & 8.000 \\
$\mathrm{Y}$ & 4.662 & 4.774 & 4.876 \\
$\mathrm{X}$ & 2.508 & 2.564 & 2.600 \\
$\mathrm{Fe}^{+3} / \mathrm{Fe}^{+2}$ & 0.348 & 0.326 & 0.264 \\
$\mathrm{mg}$ & 0.107 & 0.125 & 0.299 \\
\hline
\end{tabular}

tion and $\mathrm{Mg} \rightleftarrows \mathrm{Fe}^{+2}$ substitution are recognized. $\mathrm{TiO}_{2}$ content is lower than that of the igneous ferrohastingsites. When general formula of calciferous amphiboles is expressed as $\mathrm{X}_{2-3} \mathrm{Y}_{5} \mathrm{Z}_{8} \mathrm{O}_{22}(\mathrm{OH})_{2}$, hastingsitic hornblendes from this district are always deficient in $\mathrm{Y}$ site ions. This fact may be explained as the result of oxidation of some $\mathrm{Fe}^{+2}$ in $\mathrm{Y}$ site. Thus, these hornblendes 
become more deficient in $\mathrm{Y}$ site ions with increasing $\mathrm{Fe}^{+3} / \mathrm{Fe}^{+2}$ ratios.

Chemically, hastingsitic hornblendes of the district are close to that from the Moji Mine, Fukuoka Prefecture (Matsumoto, 1969).

\section{ReFERENCES}

Aizawa, K. (1966), Geology and mineralization of the Akagane Mine (in Japanese with English abstract), Mining Geol., 16, 124-131.

Billings, M. (1928). The chemistry, optics and genesis of the hastingsite group of amphiboles. Aner. Mineral., 13, 287-296.

Leake, B.E. (1968), A catalog of analyzed calciferous and subcalciferous amphiboles together with their nomenclature and associated minerals. Geol. Soc. Amer. Spec. Paper, no. 98, 210p.

Matsumoto, Y. (1968), Ferrohastingsite from the Kimbu Mine, Nagano Prefecture, Japan (in Japanese with English abstract). Fac. Liboral
Arts, Nagasaki Univ., Natural Sci., 8, 39-46. (1969), Ferrohastingsite from the Moji Mine, Fukuoka Prefecture, Japan (in Japanese with English abstract). Sci. Rep. Fac. Sci. Kyushu Univ., Geology, 9, 1-7.

-_.. and Miyahisa, M. (1960), Ferrohastngsite from the Obira Mine, Kyushu, Japan (in Japanese with English abstract). Jowr. Mineral. Soc. Japan, 4, 372-382.

Miyahisa, M. and Matsumoto, Y. (1959), Ferrohastingsite and associated minerals from the Obira Mine, Ōita Prefecture, Japan. Memoir Ehime Univ., Sect. II, 3, 91-96.

Nambu, M. and 17 others. (1970). Report on the regional geology of the Tōno district (in Japanese). M.I.T.I. of Japan, 28p.

Watanabe, M. and Ko, S. (1942), Geology and ore deposits in the vicinity of Ide (in Japanese), Jour. Japan. Assoc. Mineval. Petrol. Econ. Geol., 28, 93-109.

and Yagi, K. 1953), Paragenesis of axinite and hastingsitic homblende from Kannonyama, Iwate Prefecture, Japan. Sci. Rep. Tohoku Unit. Ser. III, 4, 157-169.

岩手県, 赤金産ヘスティングス閃石孟角閃石

蟹 沢 聰 史

赤金鉱业栄釷床西方の TA-7 試錐孔加ら採取された石炭系米里屠の石英安山岩質凝灰岩山 接触変成作用を受

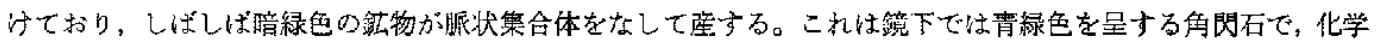
分析の結果, $\mathrm{Fe}^{+3} / \mathrm{Fe}^{+2}$ 比の高い鉄へスティングス閃石であることが分った。 